\title{
DETERMINAN PERILAKU MEROKOK PADA SISWA SMP SWASTA IMMANUEL KABANJAHE TAHUN 2020
}

\author{
Merlin Hobertin Lewerissa ${ }^{1}$, Frida Lina Tarigan ${ }^{2,}$ Wisnu Hidayat $^{3}$ \\ Program Studi Magister Kesehatan Masyarakat, Direktorat Pascasarjana, \\ Universitas Sari Mutiara Indonesia \\ frida_tarigan@yahoo.co.id ${ }^{1}$, merlinhobertin7@gmail.com ${ }^{2}$
}

\begin{abstract}
ABSTRAK
Ada banyak faktor yang melatar belakangi remaja menjadi perokok, antara lain faktor intrinsik yang meliputi faktor jenis kelamin, faktor kepribadian, faktor pekerjaan dan faktor kepercayaan. Faktor ekstrinsik meliputi pengaruh keluarga dan lingkungan sekitar, pengaruh teman sebaya, pengaruh iklim, iklan rokok, kemudahan memperoleh rokok, tidak adanya peraturan, serta sikap petugas kesehatan. Penelitian ini bertujuan untuk mengetahui faktor-faktor yang mempengaruhi perilaku merokok pada siswa Sekolah Menengah Pertama Swasta Immanuel Kabanjahe Tahun 2020. Jenis penelitian yang digunakan yaitu penelitian kualitatif dengan rancangan fenomenologi. Pengumpulan data berupa wawancara mendalam. Penentuan informan menggunakan metode purposive sampling dan di peroleh informan sebanyak 5 orang. Hasil penelitian ini menunjukkan bahwa faktor-faktor yang mempengaruhi perilaku merokok pada siswa SMP Swasta Immanuel Kabanjahe adalah faktor individu, faktor keluarga (pola asuh), riwayat keluarga. Berdasarkan hasil penelitian disarankan untuk siswa membentuk komunitas teman sebaya anti merokok supaya dapat mempromosikan mengenai prilaku merokok dan bahayanya terhadap kesehatan. Bagi orang tua agar lebih memberikan perhatian kepada anak-anaknya. Bagi sekolah agar melakukan kegiatan pelatihan UKS kepada guru BK terkait dengan rokok dan bahayanya bagi kesehatan dengan melibatkan pihak puskesmas atau dinas kesehatan.
\end{abstract}

Kata Kunci

: Perilaku Merokok Remaja, Individu (Remaja) Pola Asuh, Keluarga.

\section{ABSTRACT}

There are many factors that background teenagers into smokers, including intrinsic factors that include gender factors, personality factors, occupational factors and confidence factors. Extrinsic factors include the influence of family and the environment, peer influence, climate influence, cigarette advertising, ease of obtaining cigarettes, absence of regulation, and attitude of health officials. This study aims to find out the factors that influence smoking behavior in Junior High School school students Immanuel Kabanjahe in 2020. The type of research used is qualitative research with phenomenological design. The type of research used is qualitative research with phenomenological design. Data collection in the form of in-depth interviews. Determination of informants using purposive sampling method and obtained informant as many as 5 people. The results of this study shows the factors influenced smoking behavior in Private Junior High School student Immanuel Kabanjahe are individual factors, family factors (parenting patterns), family history. Based on the results of the study it is recommended for students to form a community of anti-smoking peers in order to promote about smoking behavior and its dangers to health. For parents to pay more attention to their children. For schools to conduct UKS training activities to BK teachers related to cigarettes and their dangers to health by involving health centers or health services.

Keywords : Adolescent smoking behavior, individual (adolescent) parenting pattern, family.

\section{PENDAHULUAN}

Perilaku merokok adalah kebiasaan yang membahayakan, meskipun setiap orang mengetahui bahaya yang disebabkan oleh rokok, namun banyak remaja yang suka merokok. Seseorang yang telah mengetahui bahaya merokok tetapi tetap meneruskan untuk merokok, tentu memiliki alasan tertentu. Alasan mereka mengkonsumsi 
benda kecil yang mengandung Tar dan Nikotin antara lain, mereka ingin tahu enaknya rokok dan sekedar ingin merasakan, mereka merasa rokok telah menjadi gaya hidup atau trend masa kini, anggapan bahwa rokok dapat menghilangkan stress, menghilangkan kejenuhan dan menghilangkan ketegangan. Adapula mereka yang beralasan rokok sebagai lambang kedewasaan, memperoleh pengalaman yang menyenangkan, kurangnya kontrol dari orang tua (Wandari, 2016).

Merokok sangat memberikan efek negative bagi anak di bawah umur baik dari aspek fisiologis maupun aspek psikologis. Merokok juga dapat mempengaruhi tingkat kecerdasan seorang anak. Seorang anak yang terbukti merokok akan memiliki tingkat kecerdasan lebih rendah dibanding anak yang tidak merokok. Hal ini menjadi serius mengingat semakin gencarnya iklan rokok yang menjadi pintu gerbang untuk membidik kalangan muda, terutama anakanak((Nugroho, 2017).

Usia perokok di Indonesia, kini semakin muda, bahkan telah menyentuh usia anak-anak. Kondisi ini yang menyebabkan Indonesia disebut sebagai satu-satunya negara didunia dengan baby smoker atau perokok anak. Prevalensi merokok pada remaja usia sekolah atau usia 10-18 tahun mengalami kenaikan tercatat sebesar 9,1\% (Riskesdas, 2018).

Ada banyak faktor yang melatar belakangi remaja menjadi perokok, antara lain faktor intrinsik yang meliputi faktor jenis kelamin, faktor kepribadian, faktor pekerjaan dan faktor kepercayaan. Faktor ekstrinsik meliputi pengaruh keluarga dan lingkungan sekitar, pengaruh teman sebaya, pengaruh iklim, iklan rokok, kemudahan memperoleh rokok, tidak adanya peraturan, serta sikap petugas kesehatan (Faridah, 2017).

Berdasarkan hasil survey awal yang peneliti lakukan melalui wawancara dengan salah satu guru SMP swasta Immanuel Kabanjahe didapatkan bahwa, banyak anak remaja sudah merokok, kadang mereka kedapatan merokok di sekitar sekolah, dan banyak kedai kedai di sekitar sekolah yang menjual rokok dengan bebas dan siapapun bisa membelinya termasuk anak yang masih remaja.

Oleh karena itu peneliti ingin mengetahui faktor-faktor yang mempengaruhi perilaku merokok pada siswa Sekolah Menengah Pertama Swasta Immanuel Kabanjahe

\section{METODE}

Penelitian ini menggunakan metode penelitian kualitatif dengan menggunakan studi fenomenologi. Penelitian dilakukan di bulan Januari 2020 sampai Agustus 2020. Informan dalam penelitian ini adalah 3 orang siswa laki laki SMP, 1 orangtua dan 1 guru Bimbingan Konseling dengan menggunakan teknik Purposive Sampling. Dalam hal ini yang akan diteliti adalah mengenai Perilaku Merokok Pada Siswa SMP Swasta Immanuel Kabanjahe.. Analisis data dalam penelitian ini menggunakan teknik analisis interactive, model dari miles dan Huberman, yang terdiri dari langkah-langkah pengumpulan data (data collection), reduksi data (data reduction), penyajian data (data display), dan penarikan kesimpulan atau verifikasi (conclusion)

\section{HASIL}

Faktor Pendorong Perilaku Merokok Pada Siswa SMP Swasta Immanuel Kabanjahe
Faktor Individu
Pada bagian ini peneliti menggali informasi dari informan dengan menanyakan alasan awal informan mulai merokok, kapan pertama kalinya informan mulai merokok, hal-hal apa saja yang dirasakan saat pertama kali merokok. Hal ini dapat dilihat seperti pada kutipan dibawah ini : 
"Awal mula aku Cuma coba-coba 1 batang, kemudian mau lagi, lama-lama kecanduan"'(JS, 14 Tahun)

"Karena ditawari sama kawan saat kumpul-kumpul waktu itu kelas 2 SMP itu pertama kalinya aku merokok"(IP, 14 Tahun)

"Pertama kali batuk-batuk, pusing gak enak tapi penasaran makanya lanjut aja merokoknya. ditawari sama teman pada saat ngumpul. Awal nya sempat batukbatuk juga tapi enak sih makanya lanjut aja merokoknya. Mulai merokok dari SMP kelas 1".(MS, 15 Tahun)

Berdasarkan hasil wawancara tersebut diketahui bahwasanya alasan informan merokok pertama-tama adalah karena rasa ingin tahu dan penasaran. Walaupun disisi lain, saat pertama kali mengkonsumsi rokok dirasakan ketidak enakan namun sebagian dari informan mengabaikan pengalaman perasaan tersebut, yang berlanjut menjadi kebiasaan dan akhirnya menjadi ketergantungan. Aktivitas merokok ini untuk sebagian informan dimulai sejak duduk di kelas 1 dan kelas 2 SMP.

Peneliti juga menggali informasi dari informan tentang berapa banyak rokok yang dapat dihabiskan dalam sehari, kapan waktunya informan biasa merokok. Hal ini dapat dilihat seperti pada kutipan dibawah ini.

"Bisa 4 sampai 6 batang sehari, saat pulang sekolah dan kalau lagi kumpul sma kawan-kawan"'(JS, 14 Tahun)

"Paling banyak 4 batang itupun kalau lagi pengin aja"(IP, 14 Tahun)

"Gak tentu bisa hanya 2 batang. Saat dirumah kawan, kalau dirumah gak berani'"(MS, 15 Tahun)

Berdasarkan hasil wawancara tersebut diketahui bahwasanya rata-rata informan bisa menghabiskan rokok dalam sehari bervariasi antara 2 sampai 6 batang dalam sehari dengan waktu saat merokok berbedabeda, ada yang saat dirumah kawan, ada yang saat pulang sekolah.

\section{Faktor Teman Sebaya}

Pada bagian ini peneliti menggali informasi dari informan dengan menanyakan bagaimana pertama kalinya informan mengenal rokok, apakah informan memiliki teman yang merokok dan bagaimana informan bisa berteman dengan mereka. Hal ini dapat dilihat seperti pada kutipan di bawah ini.

"Dari kawan, sering diajak kumpul, mereka semua merokok aku jadi ikut merokok juga”.(JS, 14 Tahun)

"Teman-teman satu sekolah, saat pulang sekolah suka diajak merokok sama. Kalau gak merokok dibilang cemen"..(IP, 14 Tahun)

"Punya, karena rumah kami berdekatan sering main sama-sama, saat itulah kami mulai merokok".(MS, 15 Tahun)

Berdasarkan hasil wawancara tersebut diketahui bahwasanya rata-rata teman bermain atau teman sebaya yang merokok merupakan faktor awal jalannya informan mengenal rokok dan melakukan perilaku merokok. Adanya teman sebaya ini karena satu sekolah dengan informan maupun karena meliliki tempat tinggal yang berdekatan dengan informan.

\section{Faktor Keluarga (Pola Asuh Orang Tua)}

Pada bagian ini peneliti menggali informasi dari informan dengan menanyakan faktor apasaja yang mendorong perilaku merokok siswa di daerah ini dan bagaimana tindakan dari orang tua ketika seorang anak ketahuan merokok, apakah perilaku merokok pada orang dewasa khususnya laki-laki di daerah kabupaten Tanah Karo menjadi contoh panutan kepada remaja untuk melakukan perilaku merokok. Hal ini dapat diketahui dari kutipan dibawah ini.

"saya kurang paham kali apakah penyebab tapi kalau kurasa ya bu kuperhatikan orang tua yang terlalu memanjakan anak dengan memberikan uang jajan yang berlebihan. Anak minta dibelikan ini itu terus langsung dikasi duitnya. Kesempatan ini dipakai oleh anak karena orang tuapun tidak 
melakkan pengawasan uangnya dipakai beli apa aja. Itu faktor pertama. Faktor yang lain menurut saya anak-anak yang orang tuanya broken home. Yang mungkin pisah, tetapi ada juga yang orang tuanya tetapi ada juga yang satu rumah tetapi mama dan papa nya tidak cakapan. Ketika mamanya ada dirumah, pergi papanya begitu sebaliknya.(IP, 14 th)

Pada bagian ini peneliti juga menggali informasi dari informan tentang apakah faktor cuaca yang dingin mempengaruhi perilaku merokok remaja. Dari hasil wawancara dapat diketahui dari kutipan dibawah ini.

"Saya rasa tidak, karena bagi kami yang sudah lahir dan besar di daerah ini, kami telah terbiasa dengan cuaca yang seperti ini. seperti contoh sekarang ini bagi ibu ini sudah dingin tetapi bagi saya ini sudah panas, saya tidak tahu kalau yang pindahan dari daerah lain kesini. Ya ditegur karena merokok tidak baik, untuk sanksi berat belum pernah" (EK, 42 Tahun)

Dari hasil wawancara tersebut dapat diketahui bahwasanya anak-anayang terlalu dimanjakan atau anak yang terlalu dituruti semua kemauannya tanpa ada pengontrolan yang dilakukan oleh orang tua menjadi faktor awal jalannya mulai mengenal rokok. Uang yang dipakai untuk membeli rokok diperoleh dari uang jajan yang diberikan orang tua. Untuk tindakan yang diberikan saat anak ketahuan merokok adalah dengan menegur. Faktor kondisi keluarga yang broken home atau faktor kondisi keluarga yang broken home atau tidak harmonis sehingga tidak ada komunikasi yang baik dalam keluarga antara ayah dan ibu, orang tua dengan anak maupun sebaliknya dapat juga menjadi penyebab jalannya remaja mengenal perilaku merokok.

Berbeda dengan factor demografi yaitu cuaca dari hasil wawancara diketahui bahwasanya udara dingin tidak menjadi faktor pendorong perilaku merokok remaja.

\section{Sikap dan Respon Guru Terhadap Perilaku Merokok Siswa}

Pada bagian ini peneliti menggali informasi dari informan dengan menanyakan faktor apasaja yang menjadi pendorong perilaku merokok bagi siswa yang ketahuan membawa rokok atau merokok di lingkungan sekolah. Pada bagian ini peneliti juga menanyakan apakah perlu dilakukan kegiatan-kegiatan sosialisasi terkait bahaya merokok kepada siswa. Hal ini dapat dilihat dari kutipan dibawah ini.

"Menurut saya faktor kurang kepedulian kepada anak, orang tua mencukupi semua keperluan anak tapi tidak peduli dengan siapa anak berteman.Tidak ada siswa kami yang berani merokok dilingkungan sekolah. Tapi kami tidak tahu kalau diluar sana. Dan kami memiliki kegiatan rutin yang dilakuan hampir satu bulan sekali yaitu razia terhadap siswa. Dan pada saat razia ini kami memang sering menemukan siswa memiliki rokok. Dan tindakan yang kami lakuan terhadap siswa tersebut yaitu dengan memberi hukungan ringan berupa peringatan pertama. Sanksi berat dilakukan dengan cara pemanggilan orang tua jika kesalahan yang sama diulang".

Guru sebagai pendidik profesional diharapakan dapat terlibat dalam upaya pencegahan perilaku merokok pada remaja. Upaya pencegahan perilaku merokok pada remaja di lingkungan sekolah antara lain guru memberi nasehat dan menghimbau murid tentang bahaya merokok, guru melakukan razia, guru memberi sanksi atau melaporkan murid ke BK.

\section{PEMBAHASAN}

\section{Faktor Individu}

Berdasarkan hasil wawancara diketahui bahwasanya para informan memiliki alasan awal untuk merokok adalah karena rasa ingin tahu (coba-coba) atau penasaran yang dimulai saat mereka duduk dikelas 1 dan 2 SMP. Hal ini terjadi karena masa remaja merupakan 
masa dimana seorang individu mengalami peralihan dari satu tahap ketahap berikutnya dan mengalami perubahan baik emosi, tubuh, minat pola perilaku, remaja sangat rentan sekali mengalami masalah-masalah dalam dirinya. Seorang remaja tidak diperbolehkan merokok dikalangan sekolah, masyarakat atau kalngan lainnya, karena hal ini dapat berdampak buruk terhadap kesehatannya. Biasanya ini dilakukan oleh para remaja karena kondidi emosi mereka yang tidak stabil membuat mereka melakukan segala hal. Karena kurangnya penyuluhan bahaya merokok dikalangan sekolah maupun masyarakat.

Berdasarkan waktu merokok diketahui bahwasanya perilaku merokok dipengaruhi oleh keadaan yang dialaminya pada saat itu. Misalnya sedang berkumpul dengan teman. Hal ini sejalan dengan penelitian yang dilakukan oleh (Astuti, 2016)

\section{Faktor Teman Sebaya}

Perilaku merokok dapat disebabkan oleh pengaruh kelompok sebaya (peer group) kelompok sebaya sering kali menjadi faktor utama dalam masalah perilaku merokok remaja. Selama masa remaja, seorang individu mulai menghabiskan lebih banyak waktu untuk teman sebaya nya dari pada dengan orang tua. Hal ini berarti bahwa teman sebaya mempunyai peran yang sangat berarti bagi remaja. Kebutuhan untuk diterima sering kali membuat remaja berbuat apasaja agar diterima kelompoknya dan terbebas dari sebutan "Banci atau cemen". Hal ini dapat dilihat pada kutipan wawncara IP (14 Tahun). Hal ini menunjukkan lingkungan pertemanan merupakan aspek yang dapat mempengaruhi perilaku merokok pada remaja. (Nugroho, 2017)

Lingkungan pertemanan menjadi aspek yang tidak dapat dihindarkan oleh para remaja dikarenakan seperti karena satu sekoah dengan informan maupun karena rumah tempat tinggal yang berdekatan. Dengan teman sebaya seseorang dapat melakukan kegiatan secara terbuka dan juga tertutup. Kelompok teman sebaya yang bersifat terbuka biasanya tidak akan menimbulkan persoalan sedangkan kelompok teman sebaya yang tertutup lebih banyak menimbulkan persoalan.
Seperti contoh perilaku merokok remaja. Semakin banyak remaja yang merokok maka semakin besar kemungkinan teman-temannya adalah perokok demikian sebaliknya.(Johnston et al., 2012)

Dari fakta tersebut ada dua kemungkinan yang terjadi, pertama informan tadi terpengaruh oleh teman-temannya atau bahkan teman-teman informan tersebut dipengaruhi oleh informan. Didalam kelompok sebaya remaja akan berusaha menemukan konsep dirinya. Kelompok sebaya akan memberikan tempat dimana nilai yang didapat bukan nilai yang diterapkan orang dewasa. Inilah letak berbahayanya bagi perkembangan jiwa remaja apabila nilai atau sikap yang dikembangkan dalam kelompok sebaya ini cenderung nilai dan sikap negatif..

Kuatnya pengaruh kelompok teman sebaya juga mengakibatkan melemahnya ikatan individu dengan orang tua, sekolah, norma-norma konvensional. Selain itu, banyak waktu yang diluangkan individu di luar rumah bersama teman-teman sebayanya dari pada dengan orang tuanya adalah salah satu alasan pokok pentingnya peran teman sebaya bagi individu

Hal ini sejalan dengan penelitian Novitasari dengen $\mathrm{P}$ value 0,002, kesimpulannya terdapat pengaruh teman sebaya terhadap perilaku merokok pada remaja di SMK Negeri 2 Yogyakarta(Novitasari, 2009)

\section{Faktor Pola Asuh}

Struktur keluarga memainkan peran yang cukup signifikan dalam hal ini, misalnya orang tua yang broken home, keluarga dengan riwayat perilaku kejam, penyia-nyiaan, pengabaian berkontribusi terhadap perilaku merokok. Pola interaksi dan hubungan dalam keluarga merupakan faktor yang juga berkontribusi terhadap perilaku merokok misalnya dalam keluarga dengan tingkat peraturan dan pengawasan yang lebih ketat akan menurunkan tingat perilaku merokok remaja. Pola asuh adalah faktor lain yang mempengaruhi perilaku merokok.(Novitasari, 2009)

Keluarga merupakan kelompok sosial pertama dalam kehidupan manusia dimana remaja belajar dan menyatakan diri sebagai 
manusia sosial, dalam interaksi dalam kelompoknya. Dalam keluarga yang sesungguhnya, komunikasi merupakan sesuatu yang harus dibina, sehingga anggota keluarga merasakan ikatan yang dalam serta saling membutuhkan. Keluarga dalam bentuk yang murni merupakan kesatuan sosial yang terdiri dari ayah, ibu dan anak-anak. Komunikasi dalam keluarga dapat berlangsung secara timbal balik dan silih berganti, bisa dari orang tua ke anak atau anak ke orang tua, atau anak ke anak. Dalam komunikasi keluarga tanggung jawab orang tua adalah mendidik anak, ada sejumlah norma yang diwariskan orang tua kepada anak maka komunikasi yang terjadi dalam keluarga bernilai pendidikan.(Keluarga et al., 2016)

Dari hasil penelitian diketahui bahwa penerapan pola asuh yang diterapkan orang tua kebanyakan adalah demokratis walaupun pola asuh demokratis banyak memiliki dampak positif, namun terkadang juga dapat menimbulkan masalah apabila anak atau orang tua kurang memiliki waktu untuk berkomunikasi.

Broken home diartikan dengan kondisi keluarga yang tidak harmonis dan tidak berjalan layaknya keluarga yang rukun, damai, dan sejahtera karena sering terjadi keributan serta perselisihan yang menyebabkan pertengkaran dan sering berakhir dalam perceraian. Broken home akhirnya sering dikaitan dengan krisis keluarga yaitu kondisi yang sangat labil dalam keluarga, dimana komunikasi dua arah dalam kondisi demokratis sudah tidak ada. Merupakan salah satu masalah yang kerap terjadi dalam kehidupan rumah tangga (Willis, Sofyan S. 2009).

Hal sejalan dengan penelitian yang dilakukan oleh Wahyuni S (2018) yang menyatakan faktor eksternal seperti pengaruh dari keluarga adalah penyebab perilaku merokok pada remaja.

\section{Sikap dan Respon Guru Terhadap Perilaku Merokok}

Guru sebagai pendidik profesional diharapakan dapat terlibat dalam upaya pencegahan perilaku merokok pada remaja. Upaya pencegahan perilaku merokok pada remaja di lingkungan sekolah antara lain guru memberi nasehat dan menghimbau murid tentang bahaya merokok, guru melakukan razia, guru memberi sanksi atau melaporkan murid ke BK. (ZURI AFRIZAL, 2017)

Dalam dunia pendidikan, rokok merupakan ancaman yang besar bagi siswa. Perilaku merokok yang ditampilkan sebagian siswa mempresentasikan hal negatif. Bahkan, bila siswa SD hingga sekolah lanjutan menjadi perokok aktif, maka mungkin anak dapat mengalami burn out (kejenuhan belajar), drop out, dan pendidikan dasar yang tidak selesai. Dalam jangka panjang, jika para siswa tidak menyelesaikan pendidikan, memiliki minat belajar rendah, negara akan menanggung kerugian sumber daya manusia yang tidak ringan. Ketika seorang siswa sedang dalam keadaan jenuh, sistem akalnya tak dapat bekerja sebagaimana yang diharapkan dalam memproses item-item informasi atau pengalaman baru sehingga kemajuan belajarnya seakan-akan jalan ditempat. Bila kemajuan belajar yang jalan ditempat ini kita gambarkan dalam bentuk kurva, yang tampak ialah garis mendatar yang lazim disebut plateau (Muhibbin Syah, 2013). Jika kejenuhan belajar dibiarkan begitu saja, siswa dapat mengalami tekanan mental dan stagnasi hasil belajar. Mereka akan cenderung berlehaleha dan tidak mampu merespons pembelajaran.

Kelelahan emosional yang dialami siswa mengakibatkan siswa berlari dari ketegangan emosi menuju perilaku terlalu santai, seperti perilaku merokok. Pada gilirannya, siswa yang telah kecanduan merokok akan sulit menahan nafsu oral untuk menghisap sehingga akan keluar kelas, membolos bahkan drop out. Tidak sedikit siswa perokok yang berawal dari hambatan akademik. Umumnya mereka tertinggal dalam mengikuti pelajaran, kurang mendapat stimulus belajar sesuai dengan kapasitas mental, dan diabaikan guru. Siswa dengan permasalahan akademik, seperti anak yang tinggal kelas, dan memiliki motivasi berprestasi rendah cenderung kehilangan kesempatan untuk mendapatkan penghargaan diri.

Sebagai upaya merespon perilaku merokok disekolah, secara repetitif, dunia pendidikan melakukan upaya yang menurut mereka preventif, misalnya razia rokok di 
kelas. Upaya klasik ini membuahkan hasil. Setidaknya sekolah bisa menandai siswasiswa yang membawa rokok dan merokok dilingkungan sekolah. Sayangnya umpan balik dari razia rokok disekolah tak selalu efektif. Banyak pendidik yang merespon perilaku merokok dengan negatif, terburuburu menghakimi siswa, dan memberi label negatif pada siswa perokok. Padahal sikap pendidik yang demikian justru akan menambah tekanan psikis pada siswa. Banyak pendidik lupa bahwa bisa jadi siswa merokok bukan karena sebuah keinginan, melainkan karena jebakan pergaulan dan budaya. Menjadi siswa perokok, abai terhadap tugas akademik, abai terhadap peraturan sekolah dan nasehat orang tua bukanlah suatu hal menyenangkan. Jauh di dalam lubuk hati siswa perokok mengemukakan kesadaran bahwa mereka ingin berubah. Sejalan dengan hal itu, tak banyak pula pendidik yang mau memahami dan berjuang mengentaskan siswa dari perilaku merokok bahkan agenda untuk mencegah perilaku merokok pada siswa pun luput dari catatan penting. Dunia pendidikan tidak bisa mengelak bahwa setiap sekolah seyogyanya memberikan perhatian besar kepada siswa, terutama mengenai pencegahan perilaku merokok. Tanpa proteksi sekolah, bebarapa anak dengan predisposisi tertentu rentan mengonsumsi rokok. Pada poin inilah sekolah perlu merekonstruksi ulang persepsi pembeljaran, guru perlu menaruh apresiasi atau proses daya juang belajar siswa dan tidak melulu pada hasil.

Berdasarkan hasil penelitian diketahui bahwa peran guru terhadap perilaku merokok siswa di SMP Swasta Immanuel telah dilakukan melalui upaya preventif seperti adanya kegiatan razia rokok setiap sebulan sekali. Dari razia ini didapatkan beberapa siswa ada yang kedapatan membawa rokok disaku celana. Tindakan yang diberikan kepada siswa ini berupa sanksi ringan yaitu peringatan jika siswa yang bersangkutan mengulang hal yang sama baru diambil tindakan pemanggilan orang tua.

\section{KESIMPULAN}

Berdasarkan hasil penelitian perilaku merokok siswa SMP Swasta Immanuel
Kabanjahe, maka dapat ditarik kesimpulan bahwa kelompok sebaya merupakan faktor utama dalam mempengaruhi perilaku merokok remaja, dan kemudian faktor pola asuh dari orangtua yang permisif dan rendahnya kelekatan antara orangtua dan anak. Dan selanjutnya sekolah dapat berperan besar dalam mencegah perilaku merokok ini, bilamana sekolah tidak perduli maka perilaku merokok dapat meningkat

\section{UCAPAN TERIMAKASIH}

Ucapan terimakasih bagi seluruh pegawai dan staf SMP Immanuel Kabanjahe.Terimakasih kepada Universitas Sari Mutiara yang telah mendukung seluruh proses penelitian ini.

\section{DAFTAR PUSTAKA}

Astuti, N. H. (2016). Merokok pintu masuk untuk penyalahgunaan narkoba jenis ganja. ARKESMAS (Arsip Kesehatan Masyarakat).

http://journal.uhamka.ac.id/index.php/ arkesmas/article/view/224/166

Johnston, V., Westphal, D. W., Earnshaw, C., \& Thomas, D. P. (2012). Starting to smoke: A qualitative study of the experiences of Australian indigenous youth. BMC Public Health, 12(1), 1. https://doi.org/10.1186/1471-2458-12963

Keluarga, P., Parent, S., Memotivasi, D., Belajar, A., Pengaruhnya, D. A. N., Perilaku, T., \& Di, M. (2016). Mutiara Jasmisari, 2016 PERANAN KELUARGA SINGLE PARENT DALAM MEMOTIVASI ANAK BELAJAR DAN PENGARUHNYA TERHADAP PERILAKU MENYIMPANG DI SEKOLAH Universitas Pendidikan Indonesia repository.upi.edu perpustakaan.upi.edu. 1-8.

Novitasari, S. (2009). Pengaruh Teman Sebaya Terhadap Perilaku Merokok Remaja Di Smk Negeri 2 Yogyakarta. Ilmu Kesehatan. 
Nugroho, R. S. (2017). Perilaku Merokok Sebagai Identitas Sosial Remaja Dalam Pergaulan Di Surabaya. Jurnal Ilmiah Departemen Sosiologi FISIP Universitas Airlangga, 22.

ZURI AFRIZAL. (2017). PERAN GURU BIMBINGAN DAN KONSELING DALAM PENANGANAN SISWA MEROKOK DI SMPN 3 KUALA NAGAN RAYA. 経済志林, 87(1,2), 149-200.

Nanang. 2016. Faktor Pendorong dan Penghambat Perubahan Perilaku Manusia

Arikunto. 2018. Prosedur Penelitian Suatu Pendekatan Prakek. Jakarta : Rineka Cipta

Departemen Kesehatan RI, 2018. Riset Kesehatan Dasar (Riskesdas). Laporan Nasional

EM Pertiwi. 2020. Faktor-Faktor Yang Berhubungan Dengan Perilaku Merokok Pada Siswa SMP Muhammadiyah 1 Palu.

Faridah, Fatin. 2017. Analisis Faktor Faktor Penyebab Perilaku Merokok Remaja di SMK " $X$ ” Surakarta

Isa, Lisna. 2017. Hubungan Tipe Kepribadian Peran Orangtua dan Sudara, Peran Teman Sebaya dan Peran Iklan Rokok Dengan Perilaku Merokok pada Siswa SMP Negeri 9 Kendari

Kemenkes, 2012. Peraturan Mentri Kesehatan Republik Indonesia No 109 Tahun 2012 tentang Pengamanan Rokok Bagi Kesehatan, Jakarta :

Khrisna, MB. 2016. Faktor Faktor Yang Mempengaruhi Perilaku Merokok

Moleong, J.Lexy.2014. Metode Penelitian Kualitatif. Bandung : PT.Remaja Rosda Karya

Monks, F. J. Koners, A. M. P. Haditono. 1999. Psikologi Perkembangan Pengantar Dalam Berbagai Bagiannya. Yogyakarta : Gajah Mada University Press.
Muhibbin Syah (penulis). (2017; (C) 2003, pada penulis). Psikologi belajar / Muhibbin Syah. Depok :: Rajawali Pers,.

Notoadmojo. S. 2014. Pengantar Pendidikan Kesehatan dan Ilmu Perilaku Kesehatan. Yogyakarta : PT Andi offset.

Permendikbud. 2015. Kawasan Tanpa Rokok Dilingkungan Sekolah

Sarwono, S. 2015. Teori-teori Psikologi Sosial. Jakarta : CV. Rajawali.

Setyani, AT. 2017. Pengaruh Merokok Bagi Remaja Terhadap Perilaku Dan Pergaulan Sehari-hari.

Sinaga, S EN. 2016. Hubungan Antara Pengetahuan Tentang Rokok, Teman Sebaya, Orang Tua yang Merokok dan Iklan Rokok.

Sodik, M.Ali. 2012. Merokok dan Bahayanya: Institusi Kesehatan Masyarakat Strada Indonesia

Syaifudin, Hidayana. 1999. Seksualitas Remaja. Jakarta : Pustaka Sinar

Willis, Sofyan. S. 2009. Konseling Keluarga. Bandung Alfabeta. 